\title{
How Governance Practices Shape and Influence Oil Palm Co-operative Performance in Malaysia
}

\section{Zaifalaila Zakaria, Abdul Rahman Abdul Rahim, Zaki Aman}

To Link this Article: http://dx.doi.org/10.6007/IJARBSS/v11-i4/8583

DOI:10.6007/IJARBSS/v11-i4/8583

Received: 23 February 2021, Revised: 26 March 2021, Accepted: 17 March 2021

Published Online: 29 April 2021

In-Text Citation: (Zakaria et al., 2021)

To Cite this Article: Zakaria, Z., Rahim, A. R. A., \& Aman, Z. (2021). How Governance Practices Shape and Influence Oil Palm Co-operative Performance in Malaysia. International Journal of Academic Research in Business and Social Sciences, 11(4), 1222-1238.

\section{Copyright: (c) 2021 The Author(s)}

Published by Human Resource Management Academic Research Society (www.hrmars.com)

This article is published under the Creative Commons Attribution (CC BY 4.0) license. Anyone may reproduce, distribute, translate and create derivative works of this article (for both commercial and non-commercial purposes), subject to full attribution to the original publication and authors. The full terms of this license may be seen at: http://creativecommons.org/licences/by/4.0/legalcode

\section{Vol. 11, No. 4, 2021, Pg. 1222 - 1238}

Full Terms \& Conditions of access and use can be found at http://hrmars.com/index.php/pages/detail/publication-ethics 


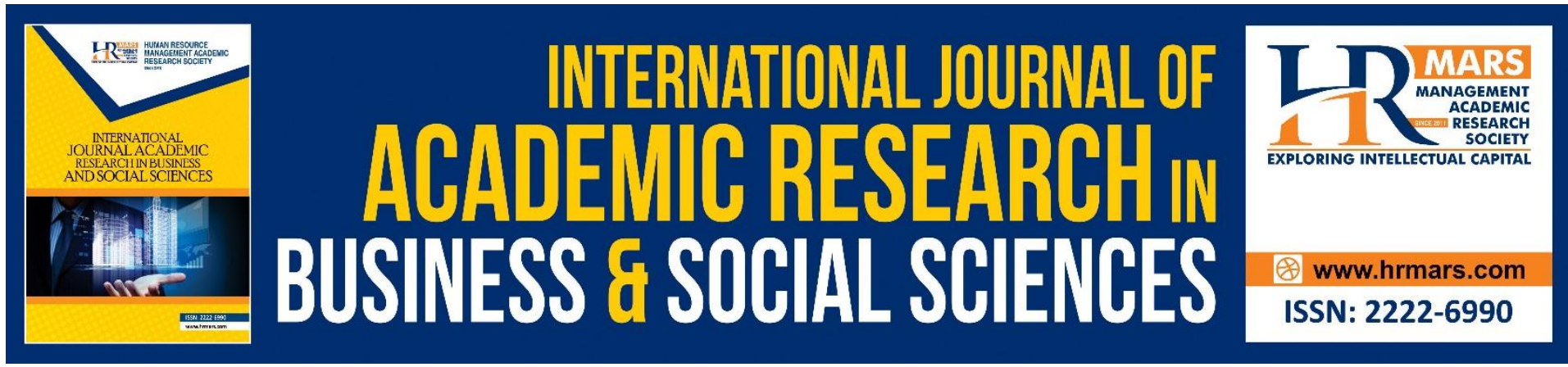

\title{
How Governance Practices Shape and Influence Oil Palm Co-operative Performance in Malaysia
}

\author{
Zaifalaila Zakaria \\ Faculty of Business and Management, Universiti Teknologi MARA, Shah Alam, Malaysia \\ Email: zaifalaila@outlook.my
}

Abdul Rahman Abdul Rahim

Arshad Ayub Graduate Business School, Universiti Teknologi MARA, Shah Alam, Malaysia

Email:aman@uitm.edu.my

Zaki Aman

Malaysian Palm Oil Board, Bangi, Malaysia

Email: zaki@mpob.gov.my

\begin{abstract}
Governance practices (GP) depict various conceptual designs, yet there are still limited investigations on how GP can influence the performance of the co-operatives. This signified that the most excellent practices from corporate governance literature might not be relevant to co-operatives because they have dual-pronged economic and social objectives for their members. In the case of the Malaysian palm oil sector, the independent oil palm smallholders or growers are encouraged to establish a co-operative to manage their farms and economic activities while finding a solution to the local community's contemporary conundrums. However, the oil palm smallholders are often neglected in the palm oil sector's complex value chain due to the remoteness of smallholders from farm knowledge and training infrastructure, and poor farm management. Realising these challenges, the oil palm cooperatives need to implement a comprehensive GP to manage their agricultural activities. Consequently, this study aims to examine the GP as a second-order construct to predict the performance of oil palm co-operatives. Data was obtained from board members of oil palm co-operatives and then analysed using partial least squares structural equation modelling (PLS-SEM). As per our findings, GP is validated as a second-order construct comprised of three crucial dimensions, namely, responsibility, management, and audit and control. Further, the results confirmed that GP had a positive and significant influence on co-operative performance. The contribution of this study is to guide the policymakers and co-operatives' managers to implement the palatable GP that will lead to greater performance of the cooperatives.
\end{abstract}

Keywords: Oil Palm Co-Operatives, Co-Operative Governance Practices, Co-Operative Performance, Confirmatory Composite Analysis, Pls-Sem, Malaysia 


\section{Introduction}

The debate on the performance of the co-operatives as an outcome variable, especially in the agricultural sector, has attracted fast-growing attention, given their socio-economic importance and prime mover for rural development (Arcas-Lario et al., 2014; Grashuis \& Su, 2019). However, empirical evidence on agricultural co-operative performance and its governance has been remained relatively limited compared to other forms of business entity (Benos et al., 2018; Grashuis \& Su, 2019). The plausible argument is that co-operative has a unique democratically controlled and voluntarily joint member-owned-and-governed business. Nevertheless, the significant roles of co-operatives are recognised, enhancing the well-being of the vulnerable community, and providing support tailored to their needs.

A plethora of literature endorses the sentiment that implementing sound governance practices (GP) is crucial given their dual-pronged objectives to achieve profitability while satisfying their members' needs (Grashuis, 2018; Grashuis \& Su, 2019; Kyazze et al., 2017). As supported by several studies (Achim et al., 2015; Bozec \& Dia, 2015; Halim et al., 2017; Korent et al., 2014; Sharma \& Khanna, 2014), their results have signified a positive and significant relationship between GP and business performance, and thus recognising the importance of GP in sustaining co-operative performance. However, co-operative sector performance and growth in Malaysia are still dubious, indicating the lack of holistic GP, which hinder cooperative's longevity and performance (Khan et al., 2016; Maslinawati et al., 2013; Nurhazani et al., 2016; Saleh \& Hamzah, 2017).

Notwithstanding vast literature pertaining to diverse types of co-operatives, we limit our analysis to the GP and oil palm co-operative performance. This is because oil palm cooperatives have significant roles in improving the income of smallholders and reducing ruralurban disparities (Begum et al., 2018; Zakaria et al., 2019). Furthermore, the government urges oil palm smallholders to establish a co-operative that is crucial to help them in response to the global sustainability challenges and economic uncertainties.

Therefore, this study's objective is twofold. First, to validate GP as a second-order construct and second, to examine the relationship between GP and performance in the context of oil palm co-operatives. This study has theoretical and practical contributions. The theoretical contribution is to enrich the literature on co-operative governance by suggesting a cooperative GP as a second-order construct by integrating three dimensions of GP using the confirmatory composite analysis (CCA) method. The practical contribution is to identify the palatable GP that influence the exceptional performance of oil palm co-operatives in Malaysia.

This study consists of six sections. After the brief introduction, the second section commences with a review of the literature and previous studies on conceptualisation and the relationship between GP and co-operative performance. The third section elucidates further on the methodology and results from the data analysis. Subsequently, the fourth section provides a discussion regarding the hypothesised relationship between GP and co-operative performance in the context of oil palm co-operatives. The fifth section postulates the theoretical and practical implications of this study. Finally, the main limitations and recommendation for future studies are drawn. 


\section{The Conceptualisation of Co-operative Performance and Governance Practices (GP) and Hypotheses Development \\ Co-operative Performance}

In this section, several studies from across the globe concerning the performance of the cooperatives are evaluated and deliberated. The financial indicator is the most widely used to assess co-operative performance, namely liquidity, liability and profitability (Martins \& Lucato, 2018). Echoing the similar sentiment, previous studies (Aini et al., 2014; Franken \& Cook, 2015; Hafizah Hammad Ahmad Khan et al., 2016; Martins \& Lucato, 2018; Ni Ketut, 2016; Sallehhuddin et al., 2017) on co-operative performance have frequently used revenue determined from the financial statement and standard financial ratio. However, it is found that most co-operatives made losses due to the absence of financial statements for auditing that indicate poor GP in a co-operative in Swaziland (Masuku et al., 2016).

Furthermore, it is argued that co-operative performance measurement based upon efficiency (profit/financial resources) measures does not seem adequate to estimate co-operative performance. For example, non-financial measures also reflect co-operative performance, such as community investment, customer satisfaction, level of employee retention, and shareholders' satisfaction (Shamsuddin et al., 2018). This concurred with the importance of integrating non-financial measures into the design of performance measurement to monitor co-operatives' operations (Masuku et al., 2016; Sallehhuddin et al., 2017). Thus, for this study, we suggest measurement of co-operative performance should reflect its business operation and its members' needs, which refers to both financial and non-financial indicators.

\section{Co-operative Governance Practices (GP)}

Concerning co-operatives GP, its structure consists of a member council, a board of directors, and a management team in accomplishing its members' needs and profitability (Birchall, 2017). For conceptualisation of co-operative GP, the dimensions consist of the representative system, expert system and balanced system suggested by Birchall (2017) were referred to as a starting point. As the works of Birchall (2017) was derived from the context of GP in large co-operatives mostly located in western countries, such as Fonterra from New Zealand and Mondragon from Spain, adjustments were made in order to portray the GP in the Malaysian co-operative sector better. These adjustments were made based on content validity and review of co-operatives literature to capture GP as a second-order construct (Åberg et al., 2019; Nurhazani et al., 2016; Willems et al., 2012). For example, Willems et al. (2012) proposed five subdimensions of governance quality. Inspired from the study by Nurhazani et al. (2016), GP scale and dimension is conceptualised according to three dimensions; (i) responsibility of the board members, (ii) oversight over the co-operative's management and (iii) auditing and control mechanisms, as exhibited in Table 1. Along these lines of reasonings, cooperative GP is operationalised as a second-order construct, given the multiple conceptual perspectives and interdependency dimensions that it comprises (Jarvis et al., 2003). For this present study, we propose the three dimensions because they are more relevant to the oil palm co-operatives in optimising their oil palm production while meeting their members' social needs (Ador, Siwar, and Ghazali, 2016; Shaufique, 2017). 


\section{Table 1}

The conceptualisation of the co-operative governance practices (GP)

\begin{tabular}{|c|c|c|}
\hline $\begin{array}{l}\text { Constructs } \\
\text { dimensions }\end{array}$ & and & tions \\
\hline $\begin{array}{l}\text { Co-operative } \\
\text { Governance } \\
\text { (GP) }\end{array}$ & Pra & $\begin{array}{l}\text { Situations or mechanisms of control and regulation within a } \\
\text { particular system, group or organisation (Leviten-Reid \& } \\
\text { Fairbairn, 2011). }\end{array}$ \\
\hline $\begin{array}{l}\text { Responsibility } \\
\text { (RES) }\end{array}$ & & $\begin{array}{l}\text { The roles of board members in ensuring that policies and } \\
\text { practices are effectively managed. }\end{array}$ \\
\hline $\begin{array}{l}\text { Management } \\
\text { (MAN) }\end{array}$ & & $\begin{array}{l}\text { Oversight of the co-operative strategic management and } \\
\text { financial affairs by the board members. }\end{array}$ \\
\hline $\begin{array}{l}\text { Auditing and } \\
\text { (AUD) }\end{array}$ & control & $\begin{array}{l}\text { Implementation of independent evaluations by external and } \\
\text { internal audits to ensure that check and balance exist in the co- } \\
\text { operative. }\end{array}$ \\
\hline
\end{tabular}

Source: Adapted from Malaysia Co-operative Governance Guidelines (2015) and Nurhazani et al. (2016)

\section{Hypotheses Development}

In tandem with the agency theory standpoint, it denotes that better controls, and improved transparency in GP should influence business performance. For instance, it is concluded that GP would influence the establishment of the Risk Management Committee so that the company's risks can be minimised, which resulted in the superior business performance (Halim et al., 2017). Additionally, by analysing data from 293 co-operatives in Uganda, Kyazze et al. (2017) revealed a significant and positive relationship between monitoring rights, innovation and non-financial performance. However, it is found that the relationship between the ratification of management decisions, policy compliance and non-financial performance was not statistically significant. Their findings thus demonstrated that the variance of GP implied the different effects on performance.

Interestingly, previous empirical works (Franken \& Cook, 2019; Ghosh \& Ansari, 2018; Sallehhuddin et al., 2017) have demonstrated a significant positive relationship between GP and board member characteristics (size, diversity, composition, experience, knowledge, training attendance) and co-operative performance. In line with the hypothetical cooperative structure, it is postulated that a smaller board size will lead to higher co-operative performance (Franken \& Cook, 2013, 2019; Ghosh \& Ansari, 2018). Additionally, it is revealed that board member motivation (board authority, function, board quality and skills) signified a positive and significant effect on co-operative performance (Chareonwongsak, 2017).

Enunciating opposite view is Aini et al. (2014) that implied a negative relationship between GP and co-operative performance in Malaysia. Moreover, the inconsistent relationships between board structure, diversity, process, and co-operative performance are found based on survey and accounting data on agricultural co-operatives in the US (Franken \& Cook, 2013). This warrants further attention, given that evidence of a causal relationship between cooperative GP and performance has been ambiguous as most empirical works portray agricultural co-operatives as a complex business organisation (Grashuis \& Su, 2019).

Intrigued by their inconsistent findings, GP should be put in place, as co-operatives can better consider their members' interests while progressing towards greater co-operative performance. Consequently, co-operative GP will be tested in this present study as a predictor that contributes to the co-operative performance, as suggested by Kyazze et al. (2017), who 
explicated that co-operative governance should be strengthened since it is the catalysts for the co-operative movement. Thus, the following hypotheses are proposed:

H1. GP is a second-order construct, whereby GP dimensions have a strong positive correlation with each other.

H2. There is a significant and positive relationship between GP and co-operative performance.

H2a. There is a significant and positive relationship between responsibility dimension of GP and co-operative performance.

$\mathbf{H} \mathbf{2 b}$. There is a significant and positive relationship between management dimension of GP and co-operative performance.

H2c. There is a significant and positive relationship between auditing and control dimension of GP and co-operative performance.

\section{Methodology \\ Data Collection Procedure}

This study used a purposive sampling technique. The purposive sampling technique has been applied in previous co-operative studies in Malaysia (Sallehhuddin et al., 2017; Yacob et al., 2018). Hence, the selection of oil palm co-operatives and each oil palm co-operatives' board members as the sample is according to specific characteristics. The two characteristics concerning the board members; first, they should hold the board member position such as advisor, chairman, secretary, or ordinary board members; and second, they should acknowledge the implementation of co-operative GP and have the ability to provide an opinion about co-operative performance and palm oil sector. Building upon the critical roles and responsibilities of the co-operative board members, their perceptions upon the variables would be used for this study because they are considered to be the persons with the most comprehensive knowledge as well as being responsible for the success of the co-operatives (Kari \& Othman, 2008; Maslinawati et al., 2013). We have determinedly selected the Sustainable Oil Palm Growers Co-operatives (SOPGC) for data analysis as SOPGC is a cooperative specialised in oil palm cultivation and production.

We used Cohen's power tables that suggest the 76 cases would be required as a minimum sample size by assuming a medium effect size, a power of 0.80 and alpha level of 0.05 (Cohen, 1988). A list of SOPGC is obtained from the Malaysian Palm Oil Board (MPOB), and all SOPGC were selected to avoid sampling bias. Thus, this study's sample size is 252 respondents, considering four board members would be selected from every SOPGC, which exceeded the minimum number of participants necessary to test the proposed model. A total of 252 questionnaires were sent between November and December 2020 to inquire about board members' perception regarding each construct. A total of 190 completed questionnaires were returned, producing a $75.4 \%$ response rate.

\section{Design and Measures}

Likert-type scale responses ranged from '1: totally disagree' to '5: totally agree' for the GP and co-operative performance construct are applied in this study. Regarding the GP scale and dimension, items are drawn and improved from the Malaysian Co-operatives Governance Guideline (2015) and Nurhazani et al. (2016) to measure GP in this research. Concerning cooperative performance construct, it is operationalised based on financial and non-financial parameters (product quality and productivity or yield) that are relevant in the context of oil 
palm co-operatives (Hafizah Hammad Ahmad Khan et al., 2016; Masuku et al., 2016). Table 2 shows the items used to measure the GP and co-operative performance construct.

Furthermore, a panel of five experts have reviewed the questionnaire for content validity. Additionally, a pilot test was conducted upon the 30 board members of co-operatives to ensure the questionnaire's clarity and understandability. These respondents were not included in the final survey. The pilot test confirmed that the questionnaire is reasonable and that all the board members have no difficulty answering it. The feedbacks from content validity and pilot test only involved minor phrasings on statements which were then used for the actual survey.

\section{Results and Data Analysis \\ Data Screening and Analysis}

We employs PLS-SEM to analyse the research model relationships using SmartPLS 3.2.8 software as it allows a researcher to balance explanation and prediction and its superior capability to assess a small sample size (Hair et al., 2019). Next, the data was initially screened with missing value analysis and signified that the missing values occurred randomly. During the data entry stage, we have identified that missing values of each item not exceeding $5 \%$ for each construct and used the mean of each item involved to fill the missing data (Hair et al., 2017). For this case, the responses were retained because the mean was used during the analysis in exchange. Next, we removed four questionnaires due to suspicious respondents' response patterns. Therefore, only 186 responses or $73.4 \%$, were suitable for the next analysis. Concerning sample profile, almost one-third of the respondents were between the ages of 56 and 65, 18\% were aged between 36 and 45, and 21\% were aged between 46 and 55 . The majority of the respondents held a position as an ordinary board member (57\%), while $15 \%$ were secretary, and $16 \%$ were the chairman of the oil palm co-operatives. The next data analysis follows the two procedures. First, the measurement model was evaluated. Second, the estimation of the structural model was performed for hypotheses testing.

\section{Measurement Model Assessment}

For the measurement model assessment, convergent validity, internal consistency reliability, and discriminant validity were analysed. Regarding convergent validity, each item's outer loading should be higher than 0.7 , and the average variance extracted (AVE) of each construct should be above 0.5 . However, the outer loading less than 0.7 should also be remained when the AVE for a certain construct has achieved the threshold value of 0.5 (Hair et al., 2017). As shown in Table 2, all items were retained, given that the AVE values of all constructs ranged from 0.578 to 0.727 had exceeded more than 0.5 , indicating that convergent validity was achieved. Concerning internal consistency reliability, all constructs' composite reliability (CR) had values ranged from 0.844 to 0.928 . As the CR values were above the 0.7 threshold values, this signified satisfactory internal consistency reliability (Hair et al., 2017). 
Table 2

Results of outer loadings, CA, CR and AVE for all the constructs

\begin{tabular}{|c|c|c|c|c|}
\hline Items C & Items & Loadings & CR & AVE \\
\hline \multicolumn{2}{|c|}{ Co-operative Governance Practices (GP) } & - & 0.917 & 0.503 \\
\hline \multicolumn{2}{|c|}{ Auditing and control (AUD) } & 0.846 & 0.888 & 0.727 \\
\hline AUD1 & $\begin{array}{l}\text { The co-operative maintains an objective and } \\
\text { professional. relationship among auditors, board } \\
\text { members and the management. }\end{array}$ & 0.835 & & \\
\hline AUD2 & Internal auditing is carried out periodically. & 0.857 & & \\
\hline AUD3 & $\begin{array}{l}\text { The co-operative always made known the external } \\
\text { audit's outcome to the members. }\end{array}$ & 0.865 & & \\
\hline \multicolumn{2}{|c|}{ Management (MAN) } & 0.897 & 0.844 & 0.578 \\
\hline MAN1 & $\begin{array}{l}\text { The co-operative has effective procedures to } \\
\text { handle complaints from members and other } \\
\text { stakeholders. }\end{array}$ & 0.777 & & \\
\hline MAN2 & $\begin{array}{l}\text { The co-operative consistently sends CBM for } \\
\text { courses to acquire the necessary knowledge. }\end{array}$ & 0.741 & & \\
\hline MAN3 & $\begin{array}{l}\text { The election of CBM based on their relevant } \\
\text { experiences. }\end{array}$ & 0.853 & & \\
\hline MAN4 & $\begin{array}{l}\text { The co-operative has a clear vision and mission to } \\
\text { chart its future. }\end{array}$ & 0.657 & & \\
\hline \multicolumn{2}{|c|}{ Responsibility (RES) } & 0.884 & 0.883 & 0.654 \\
\hline RES1 & $\begin{array}{l}\text { The Co-operative Board Member (CBM) meets the } \\
\text { set objectives in performing their duties. }\end{array}$ & 0.822 & & \\
\hline RES2 & $\begin{array}{l}\text { The duties of the CBM is equally divided among } \\
\text { them. }\end{array}$ & 0.867 & & \\
\hline RES3 & $\begin{array}{l}\text { The co-operative takes stern action against any } \\
\text { misconduct. }\end{array}$ & 0.762 & & \\
\hline RES4 & $\begin{array}{l}\text { The CBM adheres to the Malaysia Co-operative } \\
\text { Societies Commission (MCSC) guidelines as well as } \\
\text { the Co-operative Societies Act } 1993 \text { in governing } \\
\text { the co-operative. }\end{array}$ & 0.778 & & \\
\hline \multicolumn{2}{|c|}{ Co-operative Performance (PER) } & - & 0.928 & 0.648 \\
\hline PER1 & $\begin{array}{l}\text { The revenue of the co-operative has increased } \\
\text { over the last three years. }\end{array}$ & 0.833 & & \\
\hline PER2 & $\begin{array}{l}\text { The FFB sales done by the co-operative has } \\
\text { increased over the last three years. }\end{array}$ & 0.839 & & \\
\hline PER3 & $\begin{array}{l}\text { The quality of the oil palm has improved over the } \\
\text { last two years. }\end{array}$ & 0.790 & & \\
\hline PER4 & $\begin{array}{l}\text { The oil palm yield has improved over the last two } \\
\text { years. }\end{array}$ & 0.787 & & \\
\hline PER6 & $\begin{array}{l}\text { The co-operative encourages its members to have } \\
\text { financial savings regularly. }\end{array}$ & 0.668 & & \\
\hline PER7 & $\begin{array}{l}\text { In general, the income of the members has } \\
\text { increased after becoming members. }\end{array}$ & 0.841 & & \\
\hline
\end{tabular}




\begin{tabular}{lllll}
\hline Items Code & Items & Loadings & CR & AVE \\
\hline PER8 & $\begin{array}{l}\text { Overall, the performance of the co-operative has } \\
\text { improved over the last three years. }\end{array}$ & 0.859 & & \\
& & & \\
\hline
\end{tabular}

Note - PER5 removed due to low loading (0.224)

The 'repeated indicator approach' is applied in this study for gauging second-order construct of GP because all the indicators of each dimension are presumed to be highly correlated to meet the research's objectives (Jarvis et al., 2003; Sarstedt et al., 2019). Furthermore, GP indicators were exchangeable, and the elimination of an indicator would not alter the relevant construct's content (Jarvis et al., 2003). Following Sarstedt et al. (2019) guidelines, the reliability and validity results for second-order GP assessment has significantly been established, as shown in Figure 1. The measurement model's assessment presented in Table 2 confirms that convergent validity, $\mathrm{AVE}, \mathrm{CA}$, and $\mathrm{CR}$ requirements are met for all the first and second-order constructs of GP and co-operative performance.

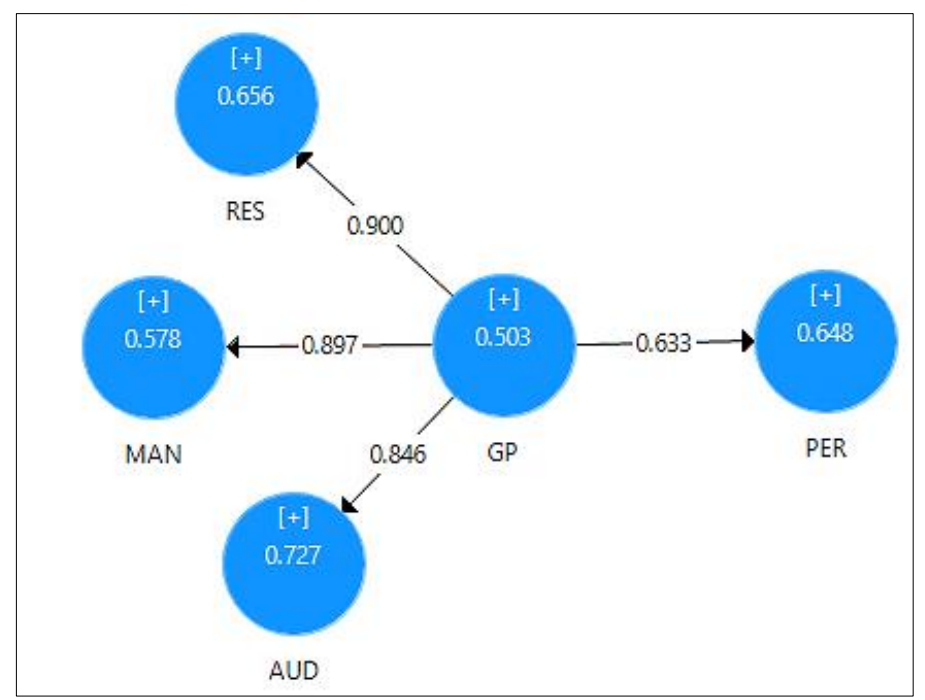

Fig. 1. Model's diagram shows loadings and AVE values

Discriminant validity is often evaluated using three approaches, namely cross-loadings, Fornell and Larcker (1981), and Heterotrait-Monotrait Ratio of Correlation (HTMT) criterion. However, it is posited that HTMT has superior performance compared to other two approaches (Henseler et al., 2015). Following Henseler et al.'s (2015) suggestion, HTMT criterion was performed to assess discriminant validity and all the HTMT values were less or equal to the threshold value of 0.90 , as shown in Table 3 . Thus, the results confirmed that this measurement model had no discriminant validity issue.

Table 3

HTMT Criterion

\begin{tabular}{lllll}
\hline & AUD & MAN & PER & RES \\
\hline AUD & - & - & - & - \\
MAN & 0.832 & - & - & - \\
PER & 0.606 & 0.692 & - & - \\
RES & 0.764 & 0.900 & 0.610 & - \\
\hline
\end{tabular}


Common methods variance (CMV) is introduced in the study, given the usage of a single informant data source (Podsakoff et al., 2003). The presence of CMV is indicated by the model's inability to achieve discriminant validity (Kline, 2013). However, we affirmed that our results had achieved satisfactory discriminant validity. This study also assessed CMV by ensuring the inner VIF values lower than 3.3, indicating the model not affected by pathological collinearity and CMV issue (Kock, 2015). Thus, CMV and lateral multicollinearity issue was not a concern in this study because all the inner VIF values were lower than 3.3, as depicted in Table 4.

\section{Table 4}

Inner VIF Values for Lateral Collinearity Assessment

\begin{tabular}{|c|c|c|c|c|}
\hline & AUD & MAN & PER & RES \\
\hline AUD & & & 1.904 & \\
\hline MAN & & & 2.384 & \\
\hline PER & & & & \\
\hline RES & & & 2.286 & \\
\hline
\end{tabular}

Two criteria were used to test the first hypothesis; outer loadings of all the first-order constructs (each of GP dimensions) on the second-order construct (see Table 2) and correlation coefficients among the dimensions presented in Table 5 . The loadings of firstorder constructs (RES, MAN, and AUD) ranged between 0.846 and 0.900 , with $50 \%$ AVE of second-order construct GP (refer to Table 2). Also, the correlations coefficients among the GP dimensions ranged between 0.628 and 0.717 (refer to Table 5), which the majority of them are higher than 0.5, represents the strong associations and interdependency (Cohen, 1988). Thus, Hypothesis $1(\mathrm{H} 1)$ is decisively supported, affirming that all dimensions (AUD, MAN, and RES) corresponding with each other.

Table 5

Correlation coefficients among GP dimensions

\begin{tabular}{llll}
\hline & AUD & MAN & RES \\
\hline AUD & 1.000 & & \\
MAN & 0.654 & 1.000 & \\
RES & 0.628 & 0.717 & 1.000 \\
\hline
\end{tabular}

\section{Structural Model Assessment}

After the measurement model assessment, the goodness of fit measures was first assessed by referring to a standardised root mean square residual (SRMR) value. The SRMR value of 0.07 was obtained, signifying a good fit as it is less than or equal to 0.08 (Hu \& Bentler, 1998). The next stage is to assess the structural model and test the proposed hypotheses. A consistent bootstrapping was applied using 5,000 bootstrap samples to derive a $95 \%$ biascorrected bootstrap confidence interval. 
Table 6

Hypotheses Testing

\begin{tabular}{|c|c|c|c|c|c|c|c|c|}
\hline Hypotheses & $\begin{array}{l}\text { Std. } \\
\text { Beta }\end{array}$ & $\begin{array}{l}\text { Std. } \\
\text { Error }\end{array}$ & $\begin{array}{l}t \\
\text { value }\end{array}$ & $\begin{array}{l}p- \\
\text { valu } \\
\text { e }\end{array}$ & $\begin{array}{l}\text { Confidence } \\
\text { BC } \\
\text { LL }\end{array}$ & $\begin{array}{l}\text { Interval } \\
\text { UL }\end{array}$ & $R^{2}$ & Decision \\
\hline H2: GP $\rightarrow>$ PER & $\begin{array}{l}0.63 \\
3\end{array}$ & $\begin{array}{l}0.04 \\
9\end{array}$ & $\begin{array}{l}12.82 \\
7\end{array}$ & $\begin{array}{l}0.00 \\
0\end{array}$ & 0.541 & 0.704 & $\begin{array}{l}0.40 \\
1\end{array}$ & $\begin{array}{l}\text { Supporte } \\
\text { d }\end{array}$ \\
\hline H2a: RES -> PER & $\begin{array}{l}0.18 \\
4\end{array}$ & $\begin{array}{l}0.08 \\
4\end{array}$ & 2.194 & $\begin{array}{l}0.01 \\
4\end{array}$ & 0.045 & 0.319 & & $\begin{array}{l}\text { Supporte } \\
d\end{array}$ \\
\hline $\begin{array}{l}\text { H2b: MAN } \rightarrow> \\
\text { PER }\end{array}$ & $\begin{array}{l}0.31 \\
5\end{array}$ & $\begin{array}{l}0.09 \\
4\end{array}$ & 3.353 & $\begin{array}{l}0.00 \\
0\end{array}$ & 0.158 & 0.466 & & $\begin{array}{l}\text { Supporte } \\
\text { d }\end{array}$ \\
\hline H2c: AUD -> PER & $\begin{array}{l}0.22 \\
4\end{array}$ & $\begin{array}{l}0.07 \\
4\end{array}$ & 3.031 & $\begin{array}{l}0.00 \\
1\end{array}$ & 0.097 & 0.339 & & $\begin{array}{l}\text { Supporte } \\
d\end{array}$ \\
\hline
\end{tabular}

Note: One-tailed test

${ }^{*} \mathrm{p}$-value $<0.05,{ }^{*} \mathrm{p}<0.01, * * * \mathrm{p}<0.001$

$\mathrm{BC}=$ bias corrected, $\mathrm{UL}=$ Upper level (5\%), LL = Lower Level $(95 \%)$.

We proposed hypotheses $(\mathrm{H} 2 \mathrm{a}, \mathrm{H} 2 \mathrm{~b}$ and $\mathrm{H} 2 \mathrm{c}$ ) between the first-order constructs of $\mathrm{GP}$ to the co-operative performance separately, and Hypothesis $2(\mathrm{H} 2)$ is recommended to assess the relationship between the second-order construct of GP to co-operative performance. Table 6 summarises the results of the hypotheses testing, revealing that the four structural paths have unique, satisfactory levels of significance and all the hypotheses underlying the model were supported. All four relationships were found to have $t$-values of more than 1.645. Consequently, the results obtained for the validated hypotheses confirmed the positive and significant effects $(p<0.01)$ for $\mathrm{H} 2, \mathrm{H} 2 \mathrm{~b}$ and $\mathrm{H} 2 \mathrm{c}$. In the case of $\mathrm{H} 2 \mathrm{a}$, the positive and significant effects were also verified, although at a different level of significance $(p<0.05)$.

The path coefficients analysis depicted that GP had the strongest positive and significant effect on co-operative performance $(\theta=0.633, t=12.827)$. While responsibility dimension (RES) had a minor effect on performance $(B=0.184, t=2.194)$, similarly auditing and control (AUD) had a less intense but still positively and significantly influenced on co-operative performance $(\theta=0.224, t=3.31)$ and management dimension (MAN) had a slightly high effect $(B=0.315, t=3.353)$ compared to other two dimensions. Furthermore, the confidence interval values do not straddle between a 0 , indicating the existence of significant results (Ramayah et al., 2019). Importantly, when the co-operative is implementing GP holistically, it has the highest $t$-value and strongest effect on co-operative performance $(B=0.633, t$-value $=12.827)$. The $R^{2}$ value of 0.401 , which explained that $40.1 \%$ of the variance in performance is above the 0.26 threshold value, thus indicating a reasonable and substantial model, as suggested by Cohen (1988).

\section{Discussion}

This study reveals the importance of the holistic adoption and parsimonious GP model in predicting performance in the context of oil palm co-operatives. The results show that complementing and corroborating all the GP dimensions by the co-operative in an equal and comprehensive nature is utmost necessary (supporting $\mathrm{H} 1$ ). It implies that the synergistic relationship between GP dimensions is crucial, which are valuable for achieving greater cooperative performance. The results provide further confirmation on the holistic implementation of GP rather than the fragmented adoption of GP in co-operatives. When 
members support the holistic adoption of GP, the objectives of satisfying its members' needs and profitability could be attained, leading to the increment in member's equity. Furthermore, a result of holistic GP will lead to co-operatives' sustainable growth over lengthy periods by obtaining higher advantages in new strategic investment and business expansion result from the implementation of holistic GP. This finding coincides with Kyazze et al. (2017), who highlighted the importance of GP towards various business performances. Thus, cooperatives should simultaneously consolidate and implement all the GP dimensions, rather than picking up one practice over others. Importantly, this study conveys a message that the partial adoption of GP may fail to enhance co-operatives' ultimate performance.

Given that the agricultural co-operatives' members have numerous roles, namely owners, growers, buyers, sellers, controllers, and workers, these diverse roles may also have different objectives and conflicting interests that could lead managers to adopt opportunistic behaviour that does not benefit the co-operative members (Arcas-Lario et al., 2014). As grounded by agency theory, a divergence of objectives will lead to principal-agent conflicts and high agency costs. This could be mitigated when the implementation of GP will control the opportunistic and self-interest behaviours of co-operative members, board of directors and professional managers through auditing and control mechanism ( $\mathrm{H} 2 \mathrm{c}$ is supported). Thus, co-operatives must rely on auditing and control mechanism to avoid agency problems (ArcasLario et al., 2014). This sentiment supports $\mathrm{H} 2 \mathrm{c}$ that emphasised the auditing and control mechanism can be employed, which include the provision of incentives, independence of the external and internal audit committee, frequency of board meeting and financial reporting disclosure to ensure the principal's interest is secured and subsequently enhancing the business performance, as postulated by Halim et al. (2017). Consequently, the dimension of audit and control is proven as the critical practices towards greater transparency and accountability, which the board members must know and fully understand in line with the cooperative governing policies (Héroux \& Roussy, 2020; SKM, 2015). Consistent with a suggestion by Héroux \& Roussy (2020), it depicts that compliance with governance regulations can help organisations enhance better control and accountability.

Interestingly, the first-order constructs of GP demonstrated consistent effects on cooperative performance. The result supports the notion that GP focuses on the board members' responsibility as a critical dimension that influences co-operative performance. This dimension consists of indicators that relevant to portray the obligations of board members in fulfilling the co-operative's objectives (supporting $\mathrm{H} 2 \mathrm{a}$ ). Further, the finding supports $\mathrm{H} 2 \mathrm{~b}$, indicating that board members who have a strategic vision and mission will guide the co-operative's future direction and positively influence the co-operative performance (ArgÜden, 2016; Saleh \& Hamzah, 2017). Also, adherence to the guidelines and regulations is crucial in co-operative governance as it will also contribute to its performance. This present study also extends the findings of Nurhazani et al. (2016) by comparing the implementation of GP within different types of co-operatives and estimating the GP as a second-order construct, demonstrating the synergistic effects of all the three dimensions on co-operative performance. This finding is in line with Willems et al. (2012), who implied that devoting in GP dimensions simultaneously would lead to exceptional results and better governance quality rather than emphasising one dimension of practice at once or combining them a single score. Concisely, our results find a positive and significant relationship between GP and co-operative performance and offer evidence that three dimensions of GP, namely responsibility, management and audit and control is important for co-operative performance. 


\section{Contributions of the Study Theoretical Contribution}

The present study subsidises the body of knowledge by confirming that co-operative governance is a good predictor of co-operative performance and suggests a parsimonious GP model in the oil palm co-operative context. It demonstrates a positive association among the dimensions of GP in oil palm co-operatives. From the agency theory point of view, it demonstrates the mutually collaborative practices of co-operative governance and supports the notion that agency costs are lower in businesses with a higher GP level due to enhanced stakeholders' confidence. This notion resonates in the context of co-operative, as its members would most likely invest and participate in the co-operatives with strong implementation of GP, as such the co-operatives have greater support in terms of financial and non-financial assistance in comparison with other co-operatives that have lower GP. Thus, a positive and significant relationship between GP and co-operative performance is expected. Importantly, we imply that the variance of GP has different effects on co-operative performance, and the correlation between both first and second-order constructs might be different based on the domain of the study. Further, a contribution of this study is the identification of specific GP and performance measures that could fit business organisations with distinct characteristics such as oil palm co-operatives. Therefore, this study offers evidence that GP can be a decisive factor in understanding how it leads to performance, specifically in co-operatives with unique ownership and governance structures.

\section{Practical Contributions}

The statistical analysis results provide essential insights for policymakers and co-operative's managers. First, the strong associations among the GP as a second-order construct will shed new light and as a basis for a policy framework that encourages co-operatives to implement GP comprehensively and simultaneously to ensure the excellent benefits of sound GP. The practices should not be considered as fragmented practices; instead, they are complementing and interdependence with other dimensions. Thus, co-operatives should implement GP holistically to improve their performance. Second, the implementation of GP and the cooperative performance measures should be analysed and adapted according to their specific domain to avoid their incompatibility with the business strategy. In other words, they must be tailored depending on the specific types and context of the co-operatives. Third, to enhance the oil palm co-operative performance; besides the initiatives of implementing GP comprehensively, the oil palm co-operatives should consider other strategies such as automation and mechanisation implementation, and enhancement of agricultural extension services in response to the current competitive market with changing customer demand, climate change issues and global economic uncertainty. This would support oil palm cooperatives to augment their performance to a greater height.

\section{Limitations and Suggestions for Future Research}

In conclusion, the present study demonstrates the parsimonious model of co-operative governance and the synergistic effect of three GP dimensions in the form of a second-order construct on co-operative performance. Even though the degrees of GP implementation within the co-operatives are slightly different, GP positively and significantly associates with co-operative performance. The more extensive the implementation of GP, the higher performance gained by the co-operatives, which will benefit the individual or independent agricultural producers, including the smallholders. In this regard, co-operative board 
members must effectively implement the GP that focuses on all these three dimensions, given that the effective, holistic, and simultaneous practices of governance will lead to greater cooperative performance.

It is vital to unveil the limitations inherent in this type of study. Firstly, GP is a long-term initiative, and its benefits could not be realised in the short term. Thus, as an alternative to the cross-sectional study, a longitudinal study could be considered to enhance the accuracy of the findings. Secondly, further investigations into other different types of co-operatives could be replicated and compared to determine whether the results can be generalised. Lastly, GP adoption in oil palm co-operatives might be supported by other collaborative strategies to cope with the constantly rising stakeholders' demands that future studies could be considered. Thus, more comprehensive insights will be produced.

\section{Notes:}

1. Oil Palm is scientifically known as Elaeis guineensis as an indigenous West Africa plant grown commercially in Malaysia since 1917 (Nambiappan et al., 2018).

2. Palm oil - The oil derived from the fruits of the oil palm tree, including crude palm oil and palm kernel oil.

\section{References}

Åberg, C., Bankewitz, M., \& Knockaert, M. (2019). Service tasks of board of directors: A literature review and research agenda in an era of new governance practices. European Management Journal, 37(5), 648-663. https://doi.org/10.1016/j.emj.2019.04.006

Achim, M.-V., Borlea, S.-N., \& Mare, C. (2015). Corporate governance and business performance: Evidence for the Romanian economy. Journal of Business Economics and Management, 17(3), 458-474. https://doi.org/10.3846/16111699.2013.834841

Ador, S. F., Siwar, C., \& Ghazali, R. (2016). A review of palm oil impact on sustainability dimension: SPOC initiative for independent smallholders. International Journal of Agriculture, Forestry and Plantation, 2(feb.), 104-110.

Aini, M. Y., Hafizah, H. A. K., Zuraini, Y., \& Zaliha, H. (2014). Modelling the impact of strategic planning, structural capital, relational capital, members' participation, governance practices and human capital development on cooperatives' performance. Journal of Business and Management (COES\&RJ-JBM), 2(2), 249-256.

Arcas-Lario, N., Martín-Ugedo, J. F., \& Mínguez-Verac, A. (2014). Farmers' satisfaction with fresh fruit and vegetable marketing Spanish cooperatives: An explanation from agency theory. International Food and Agribusiness Management Review, 17(1), 127-146.

ArgÜden, Y. (2016). Responsible Boards for a Sustainable Future. The Handbook of Board Governance, 597-638. https://doi.org/10.1002/9781119245445.ch30

Begum, H., Siwar, C., Alam, L., Choy, E. A., Ishak, S., \& Alam, A. S. A. F. (2018). Enhancing sustainability amongst oil palm smallholders in Malaysia. International Journal of Agricultural Resources, Governance and Ecology, 14(1), 62. https://doi.org/10.1504/IJARGE.2018.10011894

Benos, T., Kalogeras, N., Wetzels, M., de Ruyter, K., \& Pennings, J. M. E. (2018). Harnessing a 'currency matrix' for performance measurement in cooperatives: A multi-phased study. Sustainability (Switzerland), 10(12), 4536. https://doi.org/10.3390/su10124536

Birchall, J. (2017). The governance of large co-operative businesses. https://www.ica.coop/sites/default/files/publication-files/governancereport2017coops-ukfinalweb-1823508697.pdf 
Bozec, R., \& Dia, M. (2015). Governance practices and firm performance: Does shareholders' proximity to management matter? International Journal of Disclosure and Governance, 12(3), 185-209. https://doi.org/10.1057/jdg.2014.3

Chareonwongsak, K. (2017). Enhancing board motivation for competitive performance of Thailand's co-operatives. Journal of Co-Operative Organization and Management, 5(1), 1-13. https://doi.org/10.1016/j.jcom.2017.01.001

Cohen, J. (1988). Statistical power analysis for the behavioural science. In Statistical Power Anaylsis for the Behavioural Science (2nd Edition).

Franken, J., \& Cook, M. L. (2013). Impact of board structure and process on cooperative performance. Agricultural \& Applied Economics Association's 2013 AAEA \& CAES Joint Annual Meeting, 1-35.

Franken, J., \& Cook, M. L. (2015). Informing measurement of cooperative performance. In Interfirm Networks (pp. 209-226). Springer International Publishing. https://doi.org/10.1007/978-3-319-10184-2_11

Franken, J., \& Cook, M. L. (2019). Do corporate governance recommendations apply to U.S. agricultural cooperatives? Sustainability, 11(19), 5321. https://doi.org/10.3390/su11195321

Ghosh, S., \& Ansari, J. (2018). Board characteristics and financial performance: Evidence from Indian cooperative banks. Journal of Co-Operative Organization and Management, 6(2), 86-93. https://doi.org/10.1016/j.jcom.2018.06.005

Grashuis, J. (2018). An exploratory study of ownership and governance interrelationships in traditional and hybrid farmer cooperatives. Managerial and Decision Economics, 39(6), 664-673. https://doi.org/10.1002/mde.2936

Grashuis, J., \& Su, Y. (2019). A review of the empirical literature on farmer cooperatives: Performance, ownership, governance, finance, and member attitude. Annals of Public and Cooperative Economics, 90(1), 77-102. https://doi.org/10.1111/apce.12205

Khan, H. H. A., Yaacob, M. A., Abdullah, H., \& Abu Bakar Ah, S. H. (2016). Factors affecting performance of co-operatives in Malaysia. In International Journal of Productivity and Performance Management (Vol. 65, Issue 5). http://dx.doi.org/10.1108/IJPPM-05-20140077

Hair, Hult, G. T. M., Ringle, C. M., \& Sarstedt, M. (2017). A primer on partial least squares structural equation modeling (PLS-SEM). In SAGE Publications, Inc. (Vol. 38, Issue 2). https://doi.org/10.1080/1743727X.2015.1005806

Hair, J. F., Sarstedt, M., \& Ringle, C. M. (2019). Rethinking some of the rethinking of partial least squares. European Journal of Marketing, 53(4), 566-584. https://doi.org/10.1108/EJM-10-2018-0665

Halim, E. H., Mustika, G., Sari, R. N., Anugerah, R., \& Mohd-Sanusi, Z. (2017). Corporate governance practices and financial performance: The mediating effect of risk management committee at manufacturing firms. Journal of International Studies, 10(4), 272-289. https://doi.org/10.14254/2071-8330.2017/10-4/21

Henseler, J., Ringle, C. M., \& Sarstedt, M. (2015). A new criterion for assessing discriminant validity in variance-based structural equation modeling. Journal of the Academy of Marketing Science, 43(1), 115-135. https://doi.org/10.1007/s11747-014-0403-8

Héroux, S., \& Roussy, M. (2020). Three cases of compliance with governance regulation: an organizational learning perspective. In Journal of Management and Governance (Vol. 24, Issue 2). Springer US. https://doi.org/10.1007/s10997-019-09468-y

Hu, L., \& Bentler, P. M. (1998). Fit Indices in Covariance Structure Modeling : Sensitivity to 
Underparameterized Model Misspecification. Psychological Methods, 3(4), 424-453. https://doi.org/10.1037/1082-989X.3.4.424

Jarvis, C. B., MacKenzie, S. B., \& Podsakoff, P. M. (2003). A critical review of construct indicators and measurement model misspecification in marketing and consumer research. Journal of Consumer Research, 30(2), 199-218.

https://doi.org/10.1086/376806

Kari, F., \& Othman, A. (2008). Enhancing co-operative movement to achieve Malaysia's development goals. The Role of Co-Operatives in Sustaining Development and Fostering Social Responsibility. https://doi.org/10.1109/RFIC.2003.1213898

Kline, R. B. (2013). Principles and Practice of Structural Equation Modeling (D. A. Kenny (ed.); Vol. 3). The Guilford Press.

https://www.cambridge.org/core/product/identifier/СВ09781107415324A009/type/b ook_part

Kock, N. (2015). Common method bias in PLS-SEM: A full collinearity assessment approach. International Journal of E-Collaboration, 11(4), 1-10.

https://doi.org/10.4018/ijec.2015100101

Korent, D., Đunđek, I., \& Čalopa, M. K. (2014). Corporate governance practices and firm performance measured by Croatian Corporate Governance Index (CCGI ${ }^{\circledR}$ ). Economic Research-Ekonomska Istraživanja, 27(1), 221-231.

https://doi.org/10.1080/1331677X.2014.952109

Kyazze, L. M., Nkote, I. N., \& Wakaisuka-Isingoma, J. (2017). Cooperative governance and social performance of cooperative societies. Cogent Business and Management, 4(1), 114. https://doi.org/10.1080/23311975.2017.1284391

Leviten-Reid, C., \& Fairbairn, B. (2011). Multi-stakeholder governance in cooperative organizations: Toward a new framework for research? 2(2), 25-36. http://library.uniteddiversity.coop/Cooperatives/Multi-Stakeholder_Co-ops/Multistakeholder_Governance_in_Cooperative_Organizations.pdf

Martins, F. S., \& Lucato, W. C. (2018). Structural production factors' impact on the financial performance of agribusiness cooperatives in Brazil. In International Journal of Operations and Production Management (Vol. 38, Issue 3). https://doi.org/10.1108/IJOPM-10-20150637

Maslinawati, M., Intan Waheedah, O., \& Arun, M. (2013). Accountability issues and challenges: The scenario for Malaysian cooperative movement. International Journal of Economics and Management Engineering, 7(6), 1503-1508. https://doi.org/scholar.waset.org/1999.10/1437

Masuku, T. ., Masuku, M. ., \& Mutangira, J. P. . (2016). Performance of multi-purpose cooperatives in the Shiselweni Region of Swaziland. International Journal of Sustainable Agricultural Research, 3(4), 58-71.

https://doi.org/10.18488/journal.70/2016.3.4/70.4.58.71

Ni Ketut, S. A. (2016). Cooperative performance measurement as an efforts in supporting microfinance institutions business development. South East Asia Journal of Contemporary Business, Economics and Law, 9(4), 30-37.

Nurhazani, M. S., Azlan, Z. A., \& Kamarul Baharin, A. M. (2016). Investigating board of directors ' perceptions on corporate governance practice in cooperatives. International Journal of Contemporary Applied Sciences, 3(1), 265-289. www.ijcas.net

Podsakoff, P. M., MacKenzie, S. B., Lee, J.-Y., \& Podsakoff, N. P. (2003). Common method biases in behavioral research: A critical review of the literature and recommended 
remedies. Journal of Applied Psychology, 88(5), 879-903. https://doi.org/10.1037/00219010.88.5.879

Ramayah, T., Cheah, J., Chuah, F., Ting, H., \& Memon, M. A. (2019). Partial Least Squares Structural Equation Modeling (PLS-SEM) using SMARTPLS 3.0: An Updated and Practical Guide to Statistical Analysis (Second). Pearson Education.

Saleh, N. M., \& Hamzah, N. (2017). Co-operative governance and the public interest: Between control and autonomy. Jurnal Pengurusan, 51(2017), 209-224.

https://doi.org/10.17576/pengurusan-2018-51-18

Sallehhuddin, A., Said, A. M. A., Hasmanto, N., Mustafa, M. A., Jais, M., Samsudin, A., Masuod, M. S., \& Ismail, H. (2017). Crafting preliminary model for mosque cooperatives' antecedents of performance. Asian Social Science, 13(2), 116.

https://doi.org/10.5539/ass.v13n2p116

Sarstedt, M., Hair, J. F., Cheah, J. H., Becker, J. M., \& Ringle, C. M. (2019). How to specify, estimate, and validate higher-order constructs in PLS-SEM. Australasian Marketing Journal, 27(3), 197-211. https://doi.org/10.1016/j.ausmj.2019.05.003

Shamsuddin, Z., Mahmood, S., Ghazali, P. L., Salleh, F., \& Nawi, F. A. M. (2018). Indicators for Cooperative Performance Measurement. International Journal of Academic Research in Business and Social Sciences, 8(12), 577-585. https://doi.org/10.6007/IJARBSS/v8i12/5056

Sharma, J. P., \& Khanna, S. (2014). Corporate social responsibility, corporate governance and sustainability: Synergies and inter-relationships. Indian Journal of Corporate Governance, 7(1), 14-38. https://doi.org/10.1177/0974686220140102

Shaufique, S. F. (2017). Independent Smallholders in the Global Palm Oil Value Chain: A Case Study of Malaysia. Conference and Congress of the Indonesian Society and Agricultural Economics (ICC ISAE). http://www.perhepi.org/wp-content/uploads/2017/08/22.-Dr.Shaufique-F.-Siddique_ICC-ISAE_Speaker-Session-5.pdf

SKM. (2015). GP27:Garis Panduan Tadbir Urus Koperasi (pp. 1-42). Malaysia Cooperative Societies Commision. https://www.skm.gov.my/images/images/Garis-Panduan/GP27Garis-Panduan-Tadbir-Urus-Koperasi.pdf

Susanty, A., Bakhtiar, A., Puspitasari, N. B., \& Mustika, D. (2018). Performance analysis and strategic planning of dairy supply chain in Indonesia: A comparative study. International Journal of Productivity and Performance Management, 67(9), 1435-1462. https://doi.org/10.1108/IJPPM-10-2017-0250

Willems, J., Huybrechts, G., Jegers, M., Weijters, B., Vantilborgh, T., Bidee, J., \& Pepermans, R. (2012). Nonprofit Governance Quality: Concept and Measurement. Journal of Social Service Research, 38(4), 561-578. https://doi.org/10.1080/01488376.2012.703578

Yacob, Y., Ali, J. K., Roslin, R., \& Ting, H. (2018). The relationships between member participation, trust, Behavioural loyalty, and the moderating effect of ethnicity: An explanatory study of value co-creation among cooperative members in Sarawak. International Journal of Business and Society, 19(2), 505-522.

Zakaria, Z., Abdul Rahman, A. R., \& Aman, Z. (2019). Integration of Sustainability-Oriented Practices in the Oil Palm Cooperatives Performance : Proposal of a Conceptual Model. Asian Journal of Research in Business and Management, 1(2), 1-18. http://myjms.mohe.gov.my/index.php/ajrbm/article/view/7202/3001 